\title{
SIGNIFIKANSI HARGA, FASILITAS DAN LAYANAN TERHADAP KEPUASAN KONSUMEN JASA HOTEL
}

\author{
Hery Purnomo ${ }^{1}$, Rino Sardanto ${ }^{2}$, Basthoumi Muslih ${ }^{3}$ \\ 1, 2, 3 Universitas Nusantara PGRI, herypurnomo@ unpkediri.ac.id
}

\begin{abstract}
ABSTRAK
Tujuan penelitian ini untuk mengetahui seberapa besar signifikasi harga, fasilitas dan layanan yang telah dijalankan, pengaruhi kepuasan konsumen, baik secara parsial ataupun secara simultan. Riset dengan memakai pendekatan deskriptif kuantitatif, dan tata cara mengumpulkan informasi memakai angket, Sedangkan teknik analisis data dengan metode analisis regresi berganda. Besaran sampel dalam riset sebesar 80 responden, dengan metode pengambilan sampel dengan memakai tata cara probability sampling. Hasil yang ditemui bahwa harga, fasilitas dan pelayanan secara parsial dan simultan memiliki signifikansi terhadap kepuasan konsumen, pada masa pandemi covid-19. Hasil ini menunjukkan bahwa pengelolaan Hotel perlu mempertimbangkan bagaimana fasilitas dan interaksi karyawan dengan konsumen Hotel dapat dikelola dalam rangka untuk memuaskan kepuasan konsumen, yang akan membawa mereka untuk menerima harga premium dibebankan oleh pihak Hotel. Studi ini akan memungkinkan Hotel Lotus Garden \& Resort untuk menjadi lebih baik.
\end{abstract}

Kata Kunci: Fasilitas, Harga, Jasa Hotel, Kepuasan Konsumen, Pelayanan

\begin{abstract}
The purpose of this research is to know how much the significance of the price, facilities and services have been conducted, influence consumer satisfaction, either partially or simultaneously. Research using quantitative descriptive approaches, and rules for collecting information on poll use, where data analysis techniques with multiple regression analysis methods. Sample size in research of 80 respondents, with sampling method using probability sampling ordinance. The results found that prices, facilities and services are partially and simultaneously have significance to consumer satisfaction, during the Covid-19 pandemic. These results show that Hotel management needs to consider how facilities and employee interactions with Hotel consumers can be managed to satisfy consumer satisfaction, which will take them to receive premium prices charged by the Hotel. This study will allow the Lotus Garden Hotel \& Resort to be even better.
\end{abstract}

Keywords: Facilities, Price, Hotel Services, Customer Satisfaction, Service

Naskah diterima : 29-01-2021 Naskah dipublikasikan: 31-03-2021

\section{PENDAHULUAN}

Dalam industri perhotelan yang sangat kompetitif dan dinamis, penyedia layanan saat ini sedang mengembangkan berbagai strategi untuk memastikan kepuasan pelanggan (Ali et al., 2016) dan (Geissler, G. L., \& Rucks, 2011). Jelas bahwa kepuasan konsumen terkait erat dengan banyak konsep pemasaran hotel yang berhubungan dengan harga, fasilitas dan pelayanan. (Line, N. D., \& Runyan, 2012) dan (Maier, 2012) demikian juga (Ruiz \& Castro, B., \& Diaz, 2012)

Naik turunnya pengunjung hotel sangat dipengaruhi oleh dua faktor besar yaitu, faktor eksternal dan faktor internal. Faktor eksternal seperti masa pandemi covid-19 ini, yang berimbas pada faktor sosial, ekonomi dan kebijakan pemerintahan. Laporan Organisation for Economic 
Co-operation and Development (OECD) menyebutkan bahwa pandemi ini berimplikasi terhadap ancaman krisis ekonomi besar yang ditandai dengan terhentinya aktivitas produksi di banyak negara, jatuhnya tingkat konsumsi masyarakat, hilangnya kepercayaan konsumen yang pada akhirnya mengarah kepada ketidakpastian (OECD, 2020), sedangkan faktor internal berasal dari dalam perusahaan itu sendiri, seperti penetapan harga, fasilitas (sarana dan prasarana), dan pelayanan yang andal kepada pengguna jasa hotel, yang dimaksudkan untuk membuat para pengunjung merasa nyaman dan bisa bersantai dalam satu lokasi hotel saja, sehingga pengunjung merasa dimanjakan oleh kenyamanan yang telah diberikan.

Kepuasan konsumen dapat diketahui jika konsumen sudah menggunakan suatu jasa. Konsumen dapat mengalami tingkat kepuasan atau tidak puas setelah penggunaan jasa hotel, sesuai dengan tingkat harapan konsumen yang terpenuhi (Lovelock et al., 2011). Kepuasan merupakan keadaan emosional atau reaksi setelah pembelian, yang berupa tidak puas, jengkel, gembira ataupun kesenangan (Kotler \& Kellere, 2012). Jika Konsumen tidak puas, akan berpotensi untuk melahirkan masalah baru, sebab cenderung untuk menyebarkan keadaan emosionalnya (berita negatif) untuk calon konsumen lainnya. Kepuasan konsumen merupakan sebuah reaksi emosional jangka pendek pelanggan terhadap kinerja jasa tertentu. (Lovelock et al., 2011)

Berbagai tingkat kepuasan atau tidak-puas yang dialami konsumen, sejauh mana harapan pelanggan terpenuhi atau terlampaui. Harga merupakan salah satu pertimbangan para konsumen dalam memilih kamar di hotel tersebut. Dengan harga sesuai harapan konsumen, maka konsumen tidak perlu ragu melakukan pilihan dalam memilih fasilitas ruangan hotel tersebut dan konsumen akan merasa puas. Harga yang ditetapkan pada dasarnya ditujukan untuk memberi nilai atas produk yang telah diciptakan. (Kotler \& Kellere, 2012). Dalam penelitian terdahulu, hasil penelitian menunjukkan bahwa harga secara parsial berpengaruh sebesar 37\% terhadap kepuasan konsumen Hotel Amanda Hills Bandungan (Susilo, Heri, 2018), hasil penelitian di Hotel Grand Aquila Bandung, menemukan bahwa harga berpengaruh sebesar 29\% terhadap kepuasan konsumen (Janet Arlita Rewa, 2019)

Fasilitas dikatakan sebagai sarana dan prasarana yang disediakan untuk dipakai atau dipergunakan serta dinikmati oleh konsumen. (Lupiyoadi \& Rambat, 2017). Dengan adanya fasilitas yang baik akan menimbulkan suatu tingkat kepuasan yang tinggi dalam benak konsumen tentang hotel tersebut. Fasilitas jasa perlu diperhatikan agar dapat menciptakan/ meningkatkan nilai lebih yang diberikan oleh konsumen. Dalam penelitian terdahulu, menyatakan keputusan memilih yang dilakukan konsumen Lotus Garden Hotel Kediri dapat dipengaruhi oleh fasilitas sebesar 73\% (Shomad, 2015), sama dengan temuan penelitian di Aston Madiun Hotel \& Conference Center ada pengaruh fasilitas sebesar 82\% terhadap Kepuasan Pelanggan (Srijani, 2017). Harga berpengaruh 17\% terhadap kepuasan konsumen di Hotel The Alana Surabaya (Efrianto, 2016)

Pelayanan merupakan evaluasi pengamatan jangka panjang pelanggan terhadap penyerahan jasa, (Lovelock et al., 2011) lebih jauh, bahwa pelayanan adalah sebuah kualitas suatu pernyataan tentang sikap terhadap perbandingan antara harapan dengan kinerja (Kotler \& Kellere, 2012). Pada umumnya harapan konsumen merupakan perkiraan atau keyakinan tentang apa yang akan diterimanya apabila ia membeli atau menggunakan suatu produk baik barang maupun jasa, sedangkan kinerja atau hasil yang diterima setelah menggunakan produk yang dibeli. Penelitian terdahulu di Hotel Griya Sunset Kuta, menyatakan pelayanan berpengaruh sebesar 73\% terhadap kepuasan konsumen (Gede Mahendra, 2015), hal sama bahwa pelayanan berpengaruh signifikan sebesar 34\% terhadap kepuasan pelanggan Sulthan Hotelbanda Aceh (Kesuma et al., 2015), dan hasil penelitian di Hotel Mahkota Plengkung Kabupaten Banyuwangi menunjukkan pelayanan berpengaruh sebesar 65\% terhadap kepuasan pelanggan (Susepti et al., 
2017), hasil penelitian di Hotel Lorin Sentul bahwa pelayanan berpengaruh sebesar $21 \%$ terhadap kepuasan konsumen (Muhammad Imam Fazrurahman, Hari Muharam, 2019) dan 25\% penelitian di Hotel Baliem Pilamo Wamena (Chandra \& Tielung, 2015)

Pada saat konsumen berkeputusan untuk menggunakan jasa hotel, mempunyai pertimbangan seperti harga, fasilitas dan pelayanan yang disediakan oleh hotel tersebut. Harga, fasilitas dan pelayanan diterimanya tidak sesuai dengan harapan konsumen maka bisa diperkirakan konsumen tidak akan kembali atau bahkan konsumen akan membicarakan kepada calon konsumen lain hal-hal yang buruk dari perusahaan tersebut. Sebagai dampaknya akan merugikan perusahaan itu sendiri. Tidak mengherankan bahwa hotel yang unggul masa kini adalah yang paling memuaskan konsumen. Hotel yang unggul saat ini sangat memperhatikan mutu pelayanan memenuhi bahkan melebihi harapan konsumen, sesuai dengan penelitian di Oval Hotel Surabaya, yang menunjukkan secara secara simultan pelayanan, fasilitas dan harga berpengaruh terhadap keputusan konsumen sebesar 49\%. (Desembrianita \& Ruslin, 2016).

Rumusan masalah dalam penelitian ini adalah 1) Apakah harga berpengaruh secara signifikan terhadap kepuasan konsumen Hotel Lotus? 2) Apakah fasilitas perusahaan berpengaruh secara signifikan terhadap kepuasan konsumen Hotel Lotus? 3) Apakah pelayanan berpengaruh secara signifikan terhadap kepuasan konsumen Hotel Lotus? 4) Apakah harga, fasilitas dan pelayanan secara signifikan berpengaruh secara simultan terhadap kepuasan konsumen Hotel Lotus?

Dengan demikian manajemen hotel perlu mengetahui signifikansi harga yang telah ditetapkan, fasilitas yang disediakan, pelayanan yang ditetapkan terhadap kepuasan konsumen, baik secara parsial dan secara simultan. Hal ini serah dengan tujuan penelitian ini adalah 1) Mengetahui seberapa besar signifikansi harga, fasilitas dan pelayanan, secara parsial dan simultan terhadap Kepuasan konsumen Hotel Lotus pada masa pandemi covid-19. 2) Memberikan bahan pertimbangan bagi pihak manajemen perusahaan dalam membuat kebijakan-kebijakan yang inovatif evaluatif ditinjau dari arti penting kepuasan konsumen ditinjau dari harga, fasilitas dan pelayanan pada masa pandemi covid-19.

Untuk memenuhi tujuan penelitian diambil hipotesis, yang merupakan jawaban sementara atas suatu persoalan yang masih harus dibuktikan kebenarannya di dalam kenyataan, percobaan, atau praktik (Sugiyono, 2016). Dari hipotesis alternatif (Ha) yang akan diajukan di dalam penelitian ini yaitu sebagai berikut : H1 : Harga mempunyai signifikansi terhadap kepuasan konsumen Hotel Lotus Garden \& Resort. H2 : Fasilitas mempunyai signifikansi terhadap kepuasan konsumen Hotel Lotus Garden \& Resort. H3 : Pelayanan mempunyai signifikansi terhadap kepuasan konsumen Hotel Lotus Garden \& Resort. H4 : Harga, fasilitas dan pelayanan, secara simultan mempunyai signifikansi terhadap kepuasan konsumen Hotel Lotus Garden \& Resort.

Keseluruhan dari penelitian terdahulu, tidak memberikan penjelasan pengembangan instrumen sebagai alat ukur, dan hanya memberikan ulasan tentang indikator-indikator yang digunakan dari masing-masing variabel. Pengembangan instrumen sangat penting untuk membentuk sebuah kuesioner, sebab dari kuesioner inilah yang akan menjadi alat ukur dalam menganalisis signifikasi variabel yang satu dengan variabel lainnya. Dan disisi lain, penelitian terdahulu yang telah dilakukan sebelum pandemi covid-19, sedangkan penelitian ini dilakukan saat pandemi covid-19, di antara bulan Maret - Juli 2020. 


\section{KAJIAN LITERATUR \\ Kepuasan Konsumen}

Kepuasan konsumen adalah tanggapan konsumen (senang atau kecewa) pada evaluasi jarak yang dirasakan antara harapan (yang dipikirkan sebelumnya) dengan kinerja yang diterimanya (dirasakan) (Lovelock et al., 2011). Setiap manajemen/ pengusaha ingin memberikan jasa yang memuaskan kepada pelanggan. Kepuasan pelanggan dalam jangka panjang akan lebih menguntungkan jika mempertahankan konsumen yang setia/ loyal daripada harus terus menerus mencari/ menarik/ membina konsumen baru untuk menggantikan konsumen yang tidak melakukan pembelian ulang. Manajemen/ pengusaha banyak yang terobsesi dengan kepuasan konsumen, sebab berhubungan langsung dengan kesetiaan konsumen, pangsa pasar, dan keuntungan (Lovelock et al., 2011)

Indikator Kepuasan Konsumen sebagai evaluasi atas harapan berkaitan dengan 1) Penyediaan layanan yang baik untuk para konsumen.2) Kecepatan karyawan dalam menyelesaikan pekerjaan (efektif dan efisien), 3) Karyawan tanggap pada keluhan konsumen. 4) Karyawan mengetahui keinginan konsumen dengan melaksanakan dengan cepat, 5) Karyawan memberikan perhatian secara personal dengan baik atas keluhan konsumen secara konseptual. (Tjiptono, 2014)

\section{Harga}

Harga merupakan salah satu komponen bauran pemasaran yang memberikan pendapatan bagi manajemen/ pengusaha dan merupakan satuan moneter yang dapat ditukarkan untuk memperoleh hak kepemilikan/ penggunaan barang atau jasa (Tjiptono \& Gregorious, 2012) (Tjiptono, 2014). Harga yang telah dibayar oleh konsumen telah termasuk pelayanan, bahkan penjual juga menginginkan keuntungan dari harga yang ditetapkan itu. Dalam studi terdahulu menyatakan bahwa Harga berpengaruh terhadap kepuasan konsumen di Hotel Grand Aquila Bandung. (Arlita Rewa, 2019)

Hukum permintaan menyatakan, jumlah barang atau jasa yang dibeli akan bervariasi berbanding terbalik dengan harga. Artinya, semakin tinggi harga, maka semakin rendah kuantitas yang diminta. Dalam hukum permintaan menjelaskan sifat hubungan antara permintaan suatu barang dengan tingkat harganya. Hukum permintaan pada hakikatnya merupakan suatu hipotesis yang menyatakan bahwa makin rendah harga suatu barang maka makin banyak permintaan terhadap barang tersebut, sebaliknya makin tinggi harga suatu barang maka makin sedikit permintaan terhadap barang tersebut, dengan asumsi ceteris paribus. Ceteris paribus adalah asumsi sebuah kondisi di mana faktor lain selain faktor yang diteliti dianggap konstan alias tidak berubah, dalam hal ini agar dapat ditarik asumsi yang baik dan akurat mengenai relasi harga dengan permintaan, maka faktor-faktor lain (selain harga) harus kita anggap konstan (tidak berubah). (Sugiato, 2010)

Indikator untuk mengukur harga adalah, 1) Keterjangkauan harga. Apabila harga dirasa terjangkau maka pelanggan akan merasa cocok membeli suatu produk. 2) Kesesuaian harga dengan kualitas. Harga harus sesuai dengan kualitas yang telah dihasilkan. 3) Daya saing harga. Harga dibandingkan dengan harga jasa dari perusahaan lain apakah lebih murah atau lebih mahal. 4) Kesesuaian harga dan manfaat. Harga sudah sesuaikah dengan manfaat yang diberikan perusahaan dan diterima oleh konsumen. (Kotler \& Kellere, 2012).

\section{Fasilitas}

Fasilitas adalah alat untuk membedakan program lembaga yang satu dari pesaing yang lainnya, dan merupakan sumber daya fisik suatu jasa ditawarkan kepada konsumen (Lupiyoadi \& Rambat, 2017)(Tjiptono, 2014) . Fasilitas hotel adalah bagian usaha pariwisata yang dapat dikatakan sebagai suatu usaha akomodasi yang dikomersial dengan menyediakan fasilitas, 
seperti 1. Kamar tidur (fasilitas kamar untuk menginap tamu di hotel tersebut). Makanan dan minuman (fasilitas restoran untuk tamu mendapatkan makanan dan minuman di hotel tersebut). 2. Pelayanan penunjang lainnya (fasilitas untuk tempat rekreasi, sarana olah raga untuk tamu menginap di hotel tersebut) (Sulastiyono, 2011). Fasilitas hotel untuk memudahkan konsumen dan dapat membantu ketertarikan konsumen pada setiap situasi untuk menggunakan jasa hotel. Desain dan pengaturan fasilitas, akan membentuk persepsi konsumen. Persepsi yang dibentuk dari interaksi di antara konsumen dan fasilitas mempunyai pengaruh pada kualitas jasa di benak konsumen. Fasilitas berupa penyediaan perlengkapan-perlengkapan fisik untuk memberikan kemudahan kepada para tamu dalam melaksanakan aktivitas-aktivitas atau kegiatankegiatannya, sehingga kebutuhan-kebutuhan dapat terpenuhi selama tinggal di hotel. Dalam studi terdahulu menyatakan bahwa fasilitas hotel berpengaruh terhadap kepuasan konsumen (Gumussoy \& Koseoglu, 2016)

Indikator yang mempengaruhi penyediaan fasilitas adalah 1) Tata spasial, meliputi aspek proporsi, tekstur dan lainnya yang dikombinasikan/ dikembangkan untuk memperoleh respons intelektual maupun perasaan dari konsumen. 2) Tata ruang, mencakup interior dan arsitektur, di antaranya seperti tata letak perabotan dalam ruangan, sirkulasi udara dan lain-lain. 3) Perlengkapan/perabotan, berfungsi sebagai sarana kenyamanan, sebagai infrastruktur pendukung untuk konsumen. 4) Tata cahaya dan warna, seperti pewarnaan ruangan, tata pencahayaan yang sesuai dengan sifat aktivitas yang dilakukan, dan suasana yang dikehendaki. 5) Pesan-pesan yang disampaikan secara grafis, seperti aspek visual, penempatan bentuk fisik, pemilihan warna dan cahaya (Tjiptono, 2014)

\section{Pelayanan}

Pelayanan adalah suatu kegiatan atau urutan kegiatan yang terjadi dalam interaksi langsung antara seseorang dengan orang lain atau mesin secara fisik dengan tujuan pada kepuasan para pihak. Pelayanan merupakan suatu produk yang tidak berwujud, namun pelayanan dapat dinilai berdasarkan pengalaman dan penalaran seseorang. Pelayanan jasa hotel dapat mempengaruhi kepuasan konsumennya, dalam interaksi antara konsumen dengan pihak hotel. Sesuai dengan konsep kepuasan konsumen, bahwa kepuasan konsumen dapat tercapai bila kinerja atau hasil yang dirasakan sesuai dengan harapan konsumen. Dalam hal ini harapan konsumen hotel merupakan perkiraan apa yang diterima konsumen jika menggunakan jasa hotel, sedangkan kenyataan/ kinerja/ hasil yang diterima setelah menggunakan jasa itu. (Tjiptono, 2014). Studi terdahulu menemukan bahwa pelayanan berpengaruh terhadap kepuasan konsumen. (Ali et al., 2016).

Indikator pelayanan yang digunakan pelanggan dalam mengevaluasi kualitas jasa, antara lain : 1) Bukti Fisik. Kemampuan perusahaan dalam menunjukkan penampilan fisik kepada pelanggan, seperti penampilan fasilitas fisik, perlengkapan/ peralatan personel dan bahan komunikasi . 2) Keandalan. Kemampuan untuk melaksanakan jasa yang dijanjikan dengan andal dan akurat. 3) Ketanggapan (Daya Tanggap). Kesediaan memberikan layanan tepat waktu kepada konsumen. 4) Jaminan. Pengetahuan, kesopanan karyawan dan kemampuan untuk menunjukkan kepercayaan dan keyakinan. Empati. Kondisi memperhatikan dan memberikan perhatian pribadi kepada konsumen (Tjiptono, 2014)

\section{Kerangka Konseptual}

Kerangka konsep penelitian adalah skema hubungan antara variabel yang diamati melalui penelitian yang dilakukan. Kerangka konsep akan menyajikan ketergantungan antar variabel yang dianggap melengkapi dinamika yang diteliti, tampak pada Gambar 1.

Kepuasan konsumen merupakan perbandingan antara kenyataan yang dirasakan konsumen dengan apa yang diharapkan konsumen. Apabila yang dirasakan konsumen melebihi 
dari apa yang diharapkan, berarti konsumen telah terpenuhi kepuasannya . Kepuasan konsumen dipengaruhi oleh harga, fasilitas dan pelayanan. Harga berpengaruh signifikan terhadap kepuasan konsumen jasa hotel. Keterjangkauan harga, kesesuaian harga, daya saing harga dan kesesuaian harga dengan manfaat merupakan indikator dari harga yang mempengaruhi kepuasan konsumen. Fasilitas berpengaruh signifikan terhadap kepuasan konsumen jasa hotel. Tata ruang, perabotan dan tata cahaya merupakan indikator fasilitas yang mempengaruhi kepuasan konsumen. Pelayanan berpengaruh signifikan terhadap kepuasan konsumen di jasa hotel. Bukti fisik, keandalan, ketanggapan, jaminan dan empati merupakan indikator yang mempengaruhi kepuasan konsumen. Adanya pengaruh harga, fasilitas dan pelayanan terhadap kepuasan konsumen. perusahaan harus memperhatikan ketiga variabel tersebut agar dapat memaksimalkan dan meningkatkan dalam kepuasan konsumen.

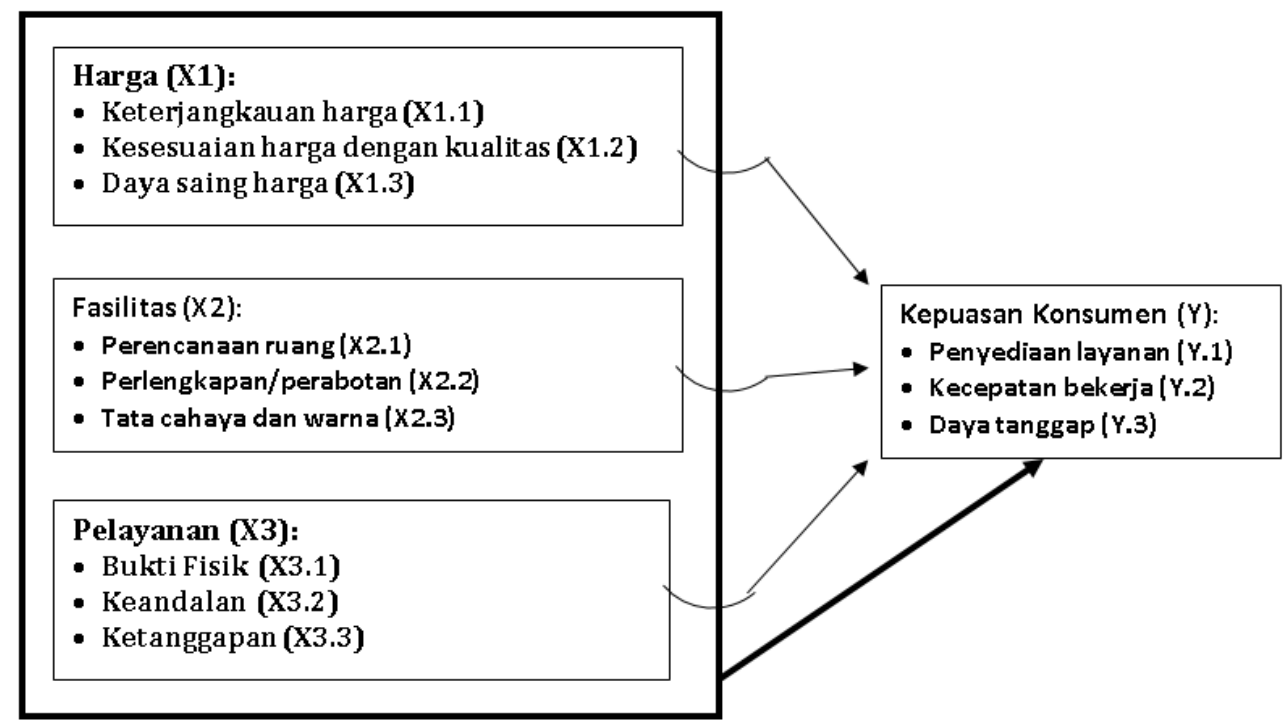

Gambar 1. Kerangka Konseptual

\section{Hipotesis}

Hipotesis merupakan suatu dugaan yang perlu diketahui kebenarannya yang berarti dugaan itu mungkin benar mungkin salah, dan harus dibuktikan kebenarannya di dalam kenyataan, percobaan, atau praktik.(Sujarweni, 2014). Hipotesis nol (H0) adalah hipotesis yang menyatakan tidak adanya hubungan antara variabel bebas dan variabel tidak bebas. Hipotesis alternatif (Ha) adalah hipotesis yang menyatakan adanya hubungan atau pengaruh antara variabel bebas dengan variabel tidak bebas. Hipotesis alternatif dalam penelitian ini adalah:

H1 : Harga berpengaruh pada kepuasan konsumen Hotel Lotus Garden \& Resort

H2 : Fasilitas berpengaruh pada kepuasan konsumen Hotel Lotus Garden \& Resort

H3 : Pelayanan berpengaruh pada kepuasan konsumen Hotel Lotus Garden \& Resort.

H4 : Harga, Fasilitas dan Pelayanan berpengaruh pada kepuasan konsumen Hotel Lotus Garden $\&$ Resort

\section{METODE PENELITIAN}

Subyek penelitian ini adalah Hotel Lotus Garden \& Resort, berdomisili di Jl. Jaksa Agung Soeprapto No 26 Kota Kediri. Objek dari penelitian ini adalah konsumen Hotel Lotus Garden.

Pendekatan Penelitian menggunakan pendekatan deskriptif kuantitatif dengan merumuskan hipotesis, selanjutnya hipotesis tersebut akan diuji, diukur, rasional dan sistematis, 
yang mana data akan analisis dengan menggunakan rumus dan uji statistika. Teknik Penelitian menggunakan metode survei, yaitu mendapatkan data sekunder dengan mengedarkan kuesioner.

Populasi penelitian adalah keseluruhan konsumen yang menggunakan jasa di Hotel Lotus \& Resort, yang sifatnya tidak terbatas. Metode pengambilan sampel dilakukan dengan menggunakan metode probability sampling yaitu metode sampling yang memberi kesempatan atau peluang yang sama untuk semua unsur dalam populasi ditetapkan sebagai sampel. Jenis probabilty sampling yang digunakan adalah simple random sampling. Dalam hal ini peneliti dalam memilih sampel dengan memberikan kesempatan yang sama kepada semua anggota populasi untuk ditetapkan sebagai anggota sampel. Adapun pertimbangan yang akan dilakukan dalam mengambil sampel yang akan diteliti yaitu responden yang diteliti adalah seseorang yang pernah menggunakan atau membeli jasa di Hotel Lotus Garden \& Resort.

Variabel bebas dalam penelitian ini antara lain Harga (X1), Fasilitas (X2), dan Pelayanan (X3) sedangkan untuk variabel terikat adalah kepuasan konsumen (Y). Pengembangan instrumen dengan memberikan Indikator variabel setiap variabel bebas dan variabel terikat (Tjiptono, Fandy, Chandra, 2011). Indikator kepuasan konsumen antara lain, 1) Penyediaan layanan yang baik, 2) Karyawan cepat menyelesaikan pekerjaan, dan 3) Karyawan tanggap pada keluhan. Indikator variabel Harga yang digunakan adalah, 1) Keterjangkauan harga, 2) Kesesuaian harga dengan kualitas, dan 3) Daya saing harga. Fasilitas merupakan segala sesuatu yang memudahkan konsumen dalam menggunakan jasa yang disediakan hotel tersebut. Indikator fasilitas adalah, 1) Perencanaan ruang, 2) Perlengkapan/ perabotan, dan 3) Tata cahaya dan warna. Indikator variabel pelayanan adalah , 1) Bukti Fisik, 2) Keandalan, dan 3) Daya Tanggap.

Pengembangan Instrumen penelitian berupa kuesioner sebagai alat ukur yang digunakan mengukur fenomena yang diamati. Pengembangan instrumen penelitian dengan memberikan dua item pertanyaan pada setiap indikatornya. Pengukuran variabel ini akan dilakukan dengan skala likert yang menggunakan metode scoring, mulai Skor 1 : Sangat tidak setuju (STS), Skor 2 : Tidak setuju (TS), Skor 3 : Kurang setuju (KS), Skor 4 : Setuju (S) dan Skor 5 : Sangat Setuju (SS). Dengan skala likert maka, variabel yang akan diukur dijabarkan menjadi indikator variabel. Kemudian indikator tersebut dijadikan sebagai titik tolak menyusun item-item instrumen yang dapat berupa pernyataan atau pertanyaan.

Kuesioner harus diuji dengan Validitas dan Reliabilitas. Uji validitas untuk mengukur sah/ valid tidak kuesioner. Kuesioner disebut valid jika pernyataan/ pertanyaan pada kuesioner tersebut mampu mengungkapkan sesuatu yang diukur dengan kuesioner itu sendiri. Uji validitas dapat diketahui dengan melihat tingkat signifikan, $r$ hitung lebih besar dari $r$ tabel dikatakan valid, dan jika sebaliknya $r$ hitung lebih kecil dari $r$ tabel dikatakan tidak valid. Kriteria yang digunakan dalam menentukan valid tidaknya pernyataan dalam penelitian, dengan nilai $\mathrm{r}$ tabel pada (df-2) dengan taraf signifikan 5\% sebesar 0,2199. Maka hasil pengujian validitas dapat ditunjukkan pada Tabel 2, $\mathrm{r}$ hitung korelasi Pearsen lebih besar dari 0,2199 maka semua pernyataan semua item pada masing-masing variabel dinyatakan valid semua.

Uji Reliabilitas digunakan untuk mengukur sah atau valid tidaknya suatu kuesioner. Kriteria yang digunakan dalam menentukan valid tidaknya pernyataan yang digunakan dalam penelitian ini dengan tingkat signifikansi 5\%. Maka hasil pengujian reliabilitas membuktikan bahwa nilai $r$ alpha hitung (cronbach's alpha) semua variabel berada $>0,60$, maka instrumen tersebut sudah reliabel.

Teknik Analisis Data yang digunakan adalah analisis regresi linear berganda, dengan menggunakan alat bantu program SPSS versi 26. Data primer dalam analisis regresi berganda harus memenuhi kriteria yang disyaratkan dalam uji normalitas, uji mutikolinieritas dan Uji heteroskedastisitas, agar hasil regresi dinyatakan layak digunakan sebagai alat analisis. 
Hasil uji normalitas, dengan metode Kolmogorov-Smirnov, didapatkan hasil Asymp. Signifikansi (2-tailed) $=0,06$ lebih besar dari 0,05, maka dapat dinyatakan bahwa nilai residual terdistribusi normal. (Ghozali, 2013)

Uji Multikolinieritas. Menunjukkan bahwa nilai semua variabel X memiliki nilai VIF lebih kecil dari 10 dan nilai tolerance yang lebih besar dari 0,10, maka dapat disimpulkan bahwa model regresi dalam penelitian ini terbebas dari gejala multikolonieritas. (Ghozali, 2013)

Uji Heteroskedastisitas. dilakukan dengan metode korelasi Spearman, dengan hasil bahwa signifikansi 2-tailed variabel indenpenden $\mathrm{X} 1=0,784, \mathrm{X} 2=0,708$ dan X3 $=0.762$ lebih besar dari 0,05 . Hal ini menyatakan bahwa varian residual model regresi ini terbebas dari gejala heterokedastisitas. (Ghozali, 2013)

Hasil kuesioner telah lolos dari uji asumsi klasik, yang harus dipenuhi dalam analisa regresi berganda, maka analisis regresi berganda dapat dilakukan dalam penelitian ini. Analisis ini digunakan untuk mencari hubungan antara harga, fasilitas dan pelayanan terhadap kepuasan konsumen, yang digambarkan dalam bentuk persamaan matematika :

$\mathrm{Y}=\mathrm{a}+\mathrm{B} 1 \mathrm{X} 1+\beta 2 \mathrm{X} 2+\beta 3 \mathrm{X} 3$

Bahwa, $Y=$ Kepuasan Konsumen, $a=$ Bilangan Konstanta, $\beta 1 \beta 2 \beta 3=$ Koefisien regresi, $X 1=$ Harga, X2 = Fasilitas, dan X3 = Pelayanan

Selanjutnya, untuk menguji taraf signifikansi masing-masing variabel bebas secara parsial terhadap sikap konsumen, digunakan uji t (uji parsial). Kriteria uji adalah jika t hitung < t tabel maka H0 diterima dan $\mathrm{H} 1$ ditolak. Hal ini diketahui tidak adanya pengaruh yang signifikan antara $\mathrm{X} 1, \mathrm{X} 2$ dan $\mathrm{X} 3$ terhadap Y1. Jika $\mathrm{t}$ hitung > t tabel maka H0 ditolak dan H1 diterima. Hal ini diketahui adanya pengaruh yang signifikan antara X1, X2 dan X3 terhadap Y1. Kriteria uji adalah jika $\mathrm{t}$ hitung $<\mathrm{t}$ tabel maka $\mathrm{H} 0$ diterima dan $\mathrm{H} 1$ ditolak. Hal ini diketahui tidak adanya pengaruh yang signifikan antara $\mathrm{X} 1, \mathrm{X} 2$ dan $\mathrm{X} 3$ terhadap $\mathrm{Y} 1$. Jika $\mathrm{t}$ hitung $>\mathrm{t}$ tabel maka $\mathrm{H} 0$ ditolak dan $\mathrm{H} 1$ diterima. Hal ini diketahui adanya pengaruh yang signifikan antara X1, X2 dan X3 terhadap Y.

Untuk menyatakan apakah semua variabel bebas yang digunakan dalam model mempunyai pengaruh secara simultan terhadap variabel terikat, digunakan uji F (uji Simultan). Kriteria untuk mengetahui apakah ada tidaknya pengaruh variabel bebas secara simultan terhadap kepuasan konsumen, adalah Jika tingkat signifikan F > 0,05 dan F hitung < F tabel, maka H0 diterima dan H1 ditolak. Uji Koefisien Determinasi (R2), digunakan untuk menyatakan besar persentase harga, fasilitas dan pelayanan secara bersama-sama mempengaruhi kepuasan konsumen.

\section{HASIL DAN PEMBAHASAN}

Hasil olah data primer dalam analisis Regresi Berganda, tampak pada Tabel 4, maka didapat sebuah persamaan regresi berganda sebagai berikut:

$\mathrm{Y}=3,272+0,340 \mathrm{X} 1+0,341 \mathrm{X} 2+0,216 \mathrm{X} 3$.

$\mathrm{a}=3,272$ memiliki arti apabila X1, X2 dan X3 diasumsikan sama dengan nol, maka variabel kepuasan konsumen sebesar 3,272. $\beta 1=0,340$ artinya jika variabel X1 mengalami kenaikan satu poin, sedangkan fasilitas dan pelayanan dianggap tetap, maka akan menyebabkan kenaikan kepuasan konsumen sebesar 0,340. $\beta 2=0,341$ artinya jika variabel $\mathrm{X} 2$ mengalami peningkatan satu poin, sedangkan X1 dan X3 tetap, maka akan menyebabkan kenaikan Y sebesar 0,341. Dan, $B 3=0,216$ artinya jika $\mathrm{X} 3$ mengalami kenaikan satu poin, sedangkan $\mathrm{X} 1$ dan $\mathrm{X} 3$ dianggap tetap, maka akan menyebabkan kenaikan kepuasan konsumen sebesar 0,216. Dengan demikian pada kondisi ceteris paribus, sumbangan kenaikan harga (X1) pada kepuasan konsumen (Y) sebesar 34\%, berlaku pula Jika ada kenaikan pada variabel fasilitas (X2) akan menyumbang kepuasan konsumen (Y) sebesar 34\%, dan 22\% untuk variabel pelayanan (X3). 
Hasil Uji t, sebagai pengujian hipotesis keberartian model regresi untuk setiap variabel dengan membandingkan $\mathrm{t}$ hitung dan $\mathrm{t}$ tabel. Dengan df 76 pada signifikan 0,05 didapat $\mathrm{t}$ tabel $=$ 1,992. Variabel X1 memiliki $\mathrm{t}$ hitung $=5,503>\mathrm{t}$ tabel $=1,992$ dan nilai probabilitas signifikansi variabel harga sebesar 0,001 $<0.05$, maka $\mathrm{H} 0$ ditolak dan $\mathrm{H} 1$ diterima, berarti diketahui X1 secara parsial bersignifikansi terhadap kepuasan konsumen, Variabel X2 memiliki t hitung = $6,429>\mathrm{t}$ tabel $=1,992$ dan nilai probabilitas signifikansi variabel fasilitas sebesar $0,000<0.05$, maka H0 ditolak dan H1 diterima, berarti diketahui X2 secara parsial bersignifikansi terhadap $\mathrm{Y}$, dan Variabel X3 memiliki $\mathrm{t}$ hitung $=3,875>\mathrm{t}$ tabel $=1,992$ dan nilai probabilitas signifikansi variabel pelayanan sebesar $0,011<0.05$, maka $\mathrm{H} 0$ ditolak dan $\mathrm{H} 1$ diterima, berarti diketahui X3 secara parsial bersignifikansi terhadap Y. Dengan demikian ketiga variabel prediktor kepuasan konsumen (Y) yaitu harga (X1), Fasilitas (X2) dan pelayanan (X3), secara parsial mempunyai signifikansi posistif dan signifikan terhadap kepuasan konsumen (Y).

Hasil Uji F menjelaskan semua variabel bebas yang digunakan mempunyai signifikansi secara bersama-sama pada variabel terikat dengan membandingkan $\mathrm{F}$ hitung dan $\mathrm{F}$ tabel. Dengan distribusi $F$ pada tingkat signifikan 0,05 didapat $F$ tabel $=2,49$. Hasil perhitungan diperoleh $\mathrm{F}$ hitung $=142.15>\mathrm{F}$ tabel $=2,49$ dengan tingkat signifikansi $0,000<0,05$, maka H0 ditolak dan H1 diterima, hal ini membuktikan bahwa variabel X1, X2 dan X3 secara simultan bersignifikansi terhadap Y. Dengan demikian ketiga variabel prediktor kepuasan konsumen (Y) yaitu harga (X1), Fasilitas (X2) dan pelayanan (X3), secara bersama-sama (simultan) mempunyai signifikansi posistif dan signifikan terhadap kepuasan konsumen (Y).

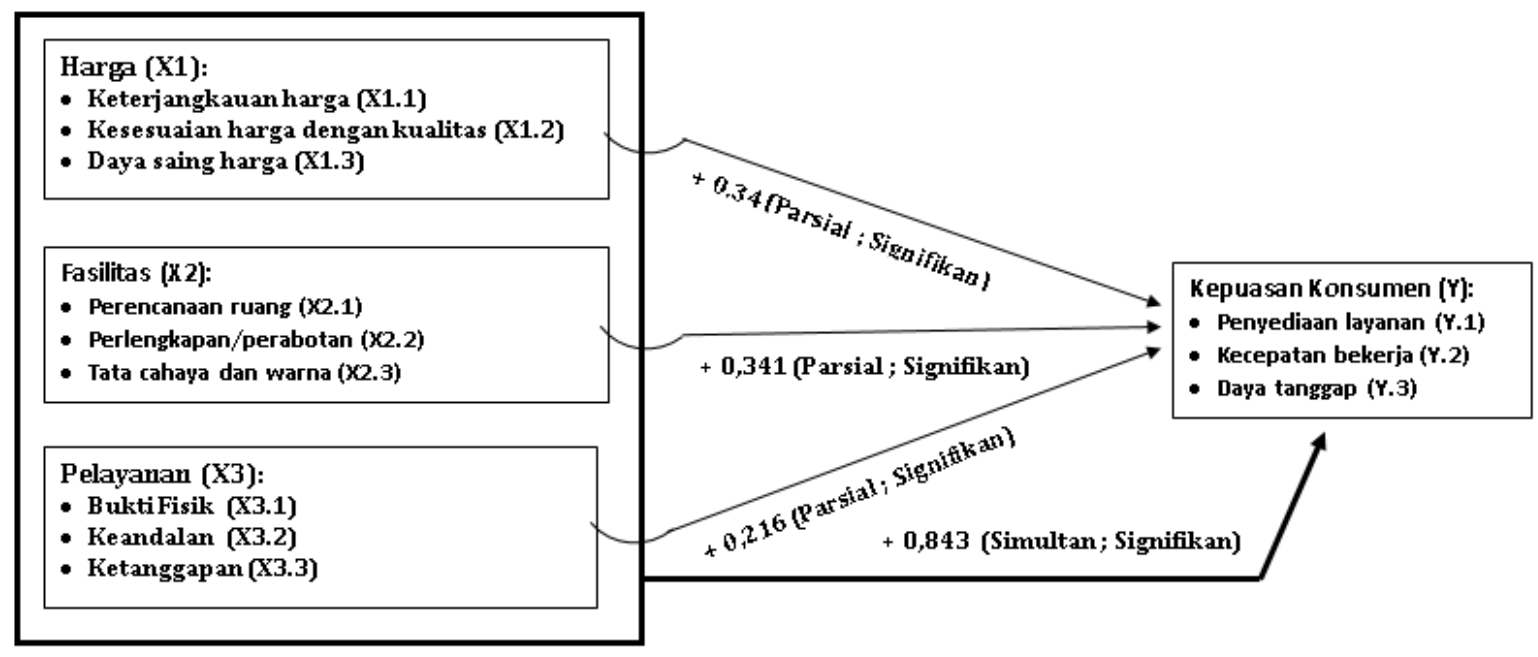

Gambar 2. Hasil Analisis dalam Kerangka Konseptual

Hasil koefisien determinasi, menjelaskan seberapa besar signifikasi variabel-variabel bebas memiliki pengaruh terhadap variabel terikat. Nilai koefisien determinasi ditentukan dengan nilai adjusted $\mathrm{R}$ square. Koefisien determinasi diperoleh nilai $\mathrm{R}$ square sebesar 0,843 . Hal ini berarti X1, X2 dan X3 dapat menjelaskan Y sebesar 84,3\%.

\section{Pembahasan.}

Harga yang sudah diterapkan mempunyai signifikansi positif terhadap kepuasan konsumen, yang mana harga memberikan kekuatan peningkatan kepuasan konsumen Hotel Lotus Garden sebesar 0,34, yang artinya harga yang terjangkau, kesesuaian harga dan daya saing harga mempengaruhi kepuasan konsumen, tetapi persentase sebesar 0,34 tergolong rendah, ini juga menunjukkan bahwa harga yang ditetapkan kurang dapat diterima oleh konsumennya. Temuan ini mendukung penelitian El-Adly yang menyatakan bahwa harga, berpengaruh positif tidak langsung signifikan terhadap kepuasan konsumen. (El-Adly, 2019) 
Fasilitas yang sudah dirasakan oleh konsumen mempunyai signifikansi positif terhadap kepuasan konsumen, dengan memberikan kekuatan peningkatan kepuasan konsumen sebesar 0,34 . Temuan ini dapat diartikan bahwa dengan penataan ruang, perlengkapan dan tata cahaya dalam penyediaan fasilitas mempengaruhi kepuasan konsumen, tetapi dengan persentase ini juga menyatakan bahwa fasilitas yang ada belum bisa diterima oleh konsumennya. Temuan ini mendukung penelitian El-Adly ditemukan bahwa fasilitas (kualitas) memiliki pengaruh positif langsung yang signifikan terhadap kepuasan pelanggan (El-Adly, 2019)

Pelayanan bersignifikansi terhadap kepuasan konsumen sebesar 0,21, maka dapat diartikan semakin baiknya pelayanan yang diberikan, semakin tinggi juga kepuasan konsumen. Hal ini dapat diartikan bahwa dengan bukti fisik, keandalan dan daya tanggap suatu pelayanan merupakan perbandingan antara harapan dan kinerja yang diterima konsumen akan mempengaruhi kepuasan konsumen, tetapi pada persentase ini menyatakan bahwa pelayanan yang diberikan oleh manajemen hotel masih kurang dapat diterima oleh konsumennya. Temuan ini mendukung penelitian Gumussoy dkk, menyatakan bahwa semua dimensi kualitas pelayanan memiliki pengaruh terhadap persepsi nilai dengan pengalaman hotel. (Gumussoy \& Koseoglu, 2016)

Harga, fasilitas dan pelayanan secara simultan bersignifikansi pada kepuasan konsumen Hotel Lotus Garden, sebesar 84\%. Persentase ini menunjukkan bahwa harga, fasilitas dan pelayanan secara bersama-sama dapat diterima oleh konsumen hotel, Kepuasan konsumen akan tinggi apabila pihak manajemen hotel melakukan ketiga prediktor ini secara bersama-sama. Temuan ini mendukung penelitian Walls dkk bahwa pengalaman konsumen menjelaskan persepsi pengalaman konsumen dalam segmen hotel. (Walls, A., Okumus, F., Wang, Y., \& Kwun, 2011)

\section{PENUTUP}

\section{Simpulan}

Sebuah model teoritis dibangun berdasarkan temuan dalam literatur, untuk menganalisis signifikansi yang didefinisikan dalam model penelitian dalam mengungkap signifikansi harga, fasilitas dan pelayanan yang sudah dijalankan manajemen hotel terdapat kepuasan konsumennya pada masa pandemi covid-19. Temuan menunjukkan bahwa harga mempunyai signifikansi positif pada kepuasan konsumen di Hotel Lotus Garden \& Resort. Semakin terjangkaunya harga yang diberikan, semakin tinggi pula kepuasan konsumen.

Temuan lain, menunjukkan fasilitas mempunyai signifikansi positif terhadap kepuasan konsumen. Semakin banyak fasilitas yang diberikan, semakin tinggi pula kepuasan konsumen. Temuan berikutnya, menyatakan pelayanan mempunyai signifikansi positif terhadap kepuasan konsumen di Hotel Lotus Garden \& Resort. Semakin baik pelayanan yang diberikan, semakin tinggi pula kepuasan konsumen.

Temuan terakhir, menunjukkan bahwa harga, Fasilitas dan pelayanan secara bersamasama mempunyai berpengaruh signifikansi terhadap kepuasan Hotel Lotus Garden \& Resort. Di sini tampak bahwa ada hubungan yang berarti harga, fasilitas dan pelayanan, merupakan variabel utama dalam pencapaian kepuasan konsumen.

Menilik bahwa signifikansi simultan pada harga, fasilitas dan pelayanan, pada kepuasan konsumen, Manajemen Hotel Lotus Garden \& Resort dapat menambah fasilitas yang berhubungan dengan protokol kesehatan untuk menghadapi pandemi Covid-19, tanpa perlu kuatir akan menurunkan kepuasan konsumen. Memang mungkin ada beban biaya tambahan untuk pengadaan alat protokol kesehatan, tetapi hal ini akan meningkatkan kepuasan konsumen Hotel, didukung dengan Harga yang bersaing dan peningkatan pelayanan dan pemahaman 
karyawan tentang protokol kesehatan. Dengan berjalannya ketiga prediktor ini secara bersamasama akan meningkatkan kepuasan konsumen.

\section{Saran}

Studi ini mengusulkan sebuah model penelitian yang mengidentifikasi prediktor signifikan kepuasan konsumen industri Hotel. Sebagai studi lebih lanjut, kami memiliki beberapa rekomendasi, antara lain: Pertama, penelitian ini didasarkan pada cara mengumpulkan data, melalui dua cara, yaitu offline (tatap muka) dan secara online (google form), peneliti berikutnya dapat melakukan identifikasi apakah kedua cara mengedarkan kuesioner, mempunyai perbedaan atau sama sebagai alat ukur penelitian. Kedua, peneliti berikutnya dapat mengembangkan instrumen dengan menambah prediktor lain, misalnya promosi hotel berbasis web, pemahaman konsumen tentang covid-19, lokasi hotel, promosi berbasis "dari mulut ke mulut" dan lainya. Ketiga, peneliti lanjut bisa mengembangkan tempat penelitian yang lebih luas, misalnya kepuasan konsumen Hotel di satu kota/ kabupaten/ provinsi/ negara, sebab ratarata penelitian terdahulu hanya terfokus pada satu hotel saja, itu pun dengan instrumen (alat ukur) yang berbeda dan terbatas. Keempat, studi lebih lanjut dapat menganalisis determinan kualitas layanan seperti praktik sumber daya manusia dan kepuasan karyawan dapat dimasukkan ke dalam model penelitian dalam rangka untuk mengungkapkan efek mereka pada kepuasan konsumen.

\section{REFERENSI}

Ali, F., Amin, M., \& Cobanoglu, C. (2016). An Integrated Model of Service Experience, Emotions, Satisfaction, and Price Acceptance: An Empirical Analysis in the Chinese Hospitality Industry. Journal of Hospitality Marketing and Management, 25(4), 449-475. https://doi.org/10.1080/19368623.2015.1019172

Arlita Rewa, J. (2019). Pengaruh Harga Dan Kualitas Pelayanan Terhadap Kepuasan Konsumen Di Hotel Grand Aquila Bandung. 3(3), 576-584.

Chandra, S. M., \& Tielung, M. V. J. (2015). Pengaruh Kualitas Pelayanan, Promosi, Dan Lokasi Terhadap Keputusan Konsumen Menggunakan Hotel Baliem Pilamo Di Wamena. Jurnal EMBA: Jurnal Riset Ekonomi, Manajemen, Bisnis Dan Akuntansi, 3(3)., 3(3). https://ejournal.unsrat.ac.id/index.php/emba/article/download/9771/9357

Desembrianita, E., \& Ruslin. (2016). Terhadap Keputusan Pelanggan Untuk Menggunakan Jasa Hotel Oval Surabaya. Jurnal Riset Ekonomi Dan Manajemen, 16(2), 345-354.

Efrianto, A. (2016). Pengaruh Harga, Lokasi, Promosi Dan Layanan Terhadap Keputusan Menginap Di Hotel The Alana Surabaya. Jurnal Ilmu Dan Riset Manajemen (JIRM), 5(September). http://jurnalmahasiswa.stiesia.ac.id/index.php/jirm/article/download/1040/1055/

El-Adly, M. I. (2019). Modelling the relationship between hotel perceived value, customer satisfaction, and customer loyalty. Journal of Retailing and Consumer Services, 50, 322332. https://doi.org/10.1016/j.jretconser.2018.07.007

Geissler, G. L., \& Rucks, C. T. (2011). The overall theme park experience: A visitor satisfaction tracking study. Journal of Vacation Marketing, 17(2), 127-138.

Gumussoy, C. A., \& Koseoglu, B. (2016). The effects of service quality, perceived value and price fairness on hotel customers' satisfaction and loyalty. Journal of Economics, Business and Management, 4(9), 9. https://doi.org/10.18178/joebm.2016.4.9.446

Janet Arlita Rewa. (2019). Pengaruh Harga Dan Kualitas Pelayanan Terhadap Kepuasan Konsumen Di Hotel Grand Aquila Bandung. Jurnal Manajemen Dan Bisnis (ALMANA), 3(3). http://journalfeb.unla.ac.id/index.php/almana/article/view/1265

Kesuma, E., Amri, \& Shabri, M. (2015). Pengaruh kualitas pelayanan dan kepercayaan terhadap kepuasan pelanggan pada sulthan hotelbanda aceh. Jurnal Manajemen Pascasarjana Universitas Syiah Kuala., 4(November 2015), 176-192. 
https://doi.org/10.2169/internalmedicine.55.5507

Kotler, P., \& Kellere, K. L. (2012). Marketing Management (14th ed.). Boston: Pearson Education Limited.

Line, N. D., \& Runyan, R. C. (2012). Hospitality marketing research: Recent trends and future directions. International Journal of Hospitality Management, 31(2), 477-188.

Lovelock, C. H., Jochen Wirtz, \& Mussry, J. (2011). Pemasaran Jasa Manusia, Teknologi, Strategi Perspektif Indonesia (1st ed.). Terjemahan Dian Wulandari dan Devri Barnadi Putera. Jilid 1. Jakarta : Erlangga.

Lupiyoadi, \& Rambat. (2017). Manajemen Pemasaran Jasa Berbasis Kompetensi. Jakarta: Salemba.

Maier. (2012). International hotel revenue management: Web-performance effec- tiveness modeling - research comparative. Journal of Hospitality and Tourism Technology, 3(2), 121-137., 3(2), 121-137.

Muhammad Imam Fazrurahman, Hari Muharam, Y. (2019). Pengaruh Kualitas Pelayanan Terhadap Kepuasan Konsumen Pada Hotel Lorin Sentul. Jurnal Online Mahasiswa (JOM) Bidang Manajemen, 4(4). https://jom.unpak.ac.id/index.php/ilmumanajemen/article/view/1303

OECD. (2020). "SME Policy Responses.” https://read.oecdilibrary.org/view/?ref=119_119680di6h3qgi4x\&title=Covid19_SME_Policy_Responses.

Ruiz, D., \& Castro, B., \& Diaz, I. (2012). Creating customer value through service ex periences: An empirical study in the hotel industry. Tourism and Hospitality Management, 18(1), 3753.

Shomad, R. (2015). Pengaruh Kondisi Lingkungan Terhadap Keputusan Konsumen Dalam Memilih Hotel (Studi Kasus Pada Lotus Garden Hotel Kediri). Jurnal Ilmiah Cendekia, 13(2), 90-99.

Srijani, N. (2017). Pengaruh Fasilitas Terhadap Kepuasan Pelanggan Di Aston Madiun Hotel \& Conference Center. Jurnal Penelitian Ilmu Ekonomi WIGA, 7, 31-38.

Sugiato, D. (2010). Ekonomi Mikro: Sebuah Kajian Komprehensif. PT.Gramedia Pustaka Utama, Jakarta.

Sugiyono. (2016). Metodologi Penelitian Bisnis (8th ed.). Bandung : Alfabeta.

Sujarweni. (2014). Metodologi Penelitian. Pustaka Baru Press, Yogyakarta.

Sulastiyono. (2011). Seri manajemen usaha jasa sarana pariwisata dan akomodasi manajemen penyelenggaraan hotel. Alfabeta, Bandung.

Susepti, A., Hamid, D., \& Kusumawati, A. (2017). Pengaruh Kualitas Pelayanan Terhadap Kepuasan Dan Loyalitas Tamu Hotel(Studi Tentang Persepsi Tamu Hotel Mahkota Plengkung Kabupaten Banyuwangi). Jurnal Administrasi Bisnis S1 Universitas Brawijaya, 50(5), 27-36.

Susilo, Heri, ect all (Fakultas E. dan B. U. P. S. (2018). Analisis Pengaruh Harga, Kualitas Pelayanan, Promosi, Dan Kepercayaan Terhadap Kepuasan Konsumen Dengan Keputusan Berkunjung Sebagai Variabel Intervening Di Hotel Amanda Hills Bandungan. http://jurnal.unpand.ac.id/index.php/MS/article/viewFile/989/964

Tjiptono, F. (2014). Pemasaran Jasa. Gramedia Cawang.

Walls, A., Okumus, F., Wang, Y., \& Kwun, D. J. W. (2011). Understanding the con- sumer experience: An exploratory study of luxury hotels. Journal of Hospitality Marketing \& Management, 20(2), 166-197. Journal of Hospitality Marketing \& Management, 20(2), 166-197. 